\title{
Factors Affecting The Performance of Health Officers in The Care of Covid-19 Patients at Murni Teguh Memorial Hospital
}

\author{
Bangbang Buhari ${ }^{1 *}$, Sri Lestari Ramadhani Nasution ${ }^{2}$, Ermi Girsang ${ }^{3}$, Chrismis \\ Novalinda Ginting ${ }^{4}$
}

${ }^{1}$ Magister Student of Magister Public Health, Faculty of Medicine, University of Prima Indonesia

${ }^{2,3,4}$ Magister Public Health, Faculty of Medicine, University of Prima Indonesia

* Corresponding author:

Email: bangbangunpri@gmail.com

\begin{abstract}
.
Covid-19 is a respiratory infection caused by the SARS-CoV-2 virus. COVID-19 is transmitted through close physical contact and respiratory droplets and can be transmitted airborne during aerosol procedures. In Indonesia as of January 21, 2021, there have been 951,651 cases with the result that 772,790 patients recovered and 27,203 people died.Nurses treat patients directly at close distances and are often directly exposed to the SARS-CoV-2 virus and have a high risk of experiencing COVID-19 disease (Hope et al, 2011). Preliminary reports suggest that the rate of COVID-19 infection among nurses is higher than during the SARS pandemic (Huang et al, 2020). The World Health Organization reports that more than 22,000 medical workers spread across 52 countries and regions have been infected with the corona virus (Covid-19). This research purpose to find out the factors that affect the performance of health workers in treating Covid-19 patients at Murni Teguh Memorial Hospital. This type of research isquantitative research with a cross sectional approach.This research was conducted in November 2021. There arethe influence of individual factors and organizational factors on the performance of health workers in treating Covid-19 patients at Murni Teguh Memorial Hospital.
\end{abstract}

Keywords: Covid-19, health workers, Covid-19 care

\section{INTRODUCTION}

Health services are the main health service industry where each hospital is responsible for the recipients of health services.Health workers, especially those in the forefront, namely doctors and nurses, have a professional obligation to treat patients in various conditions, including in pandemic conditions Coronavirus Disease (COVID19). The emergence of a pandemic Covid-19 since February 2019 until now, health services, especially to patients with Covid-19, pose a great risk to health care workers 
becoming the first victims of Covid-19, especially those on the front lines, namely doctors and nurses, which in fact poses a risk of death and impacts the performance of officers health.

Covid-19 on ainitially named 2019 novel coronavirus (2019-nCoV), then on February 11, 2020 WHO announced a new name namely Coronavirus Disease (2019nCoV) Covid-19) caused by the Severe Acute Respiratory Syndrome Coronavirus-2 (SARS-CoV-2). On March 12, 2020, WHO declared COVID-19 a pandemic (WHO, 2020a).

Patient careCovid-19, which is a very big risk for health workers, can certainly reduce the performance of officers in providing health services to patients. According to Alhakami \& Baker (2018), nurses face various difficulties in their work, such as work overload, treatment errors, unstable nurse image, decreased work motivation, and work discomfort (Fernandes et al, 2020) stated that the experience of carrying out treatment in pandemic conditions has the potential to cause long-term and short-term consequences for health workers, the social environment and the profession.

Efendi and Makhfudli (2009) state that good performance of health workers is a bridge in answering the guarantee of the quality of health services provided to patients, both sick and healthy. The main key in improving the quality of health services is health workers who have high performance. The resulting work behavior (performance) cannot be separated from the factors that influence it. According to Gibson, Ivancevich, \& Donnelly (1996) there are three groups of variables that affect work behavior and performance, namely: individual variables, psychological variables and organizational variables. The factors that affect the performance of the individual variables consist of abilities and skills, background and demographics. The factors that affect the performance of the psychological variables consist of perceptions, attitudes, personality, motivation, job satisfaction and job stress. Factors that affect the performance of organizational variables consist of resources, leadership, compensation, conflict, power, organizational structure, job design, organizational design and reward system (Ilyas, 2016).

Associated with efforts to realize the maximum performance of health workers during the current Covid-19 pandemic, support is needed both from individual, psychological and organizational factors. According to WHO in its Interim guidance on maintaining essential health services: operational guidelines for the context of Covid-19, critical supporting steps that hospital management need to take include: 1) ensuring appropriate working hours and enforcing mandatory rest periods; 2) provide guidance, training and supplies (including appropriate sized PPE for women) to limit exposure of health workers; 3) monitor illness and stress; 4) ensure physical security; 5) providing access to mental health services and self-help materials; and 6) ensure that salaries, sick leave, and overtime are paid on time. 


\section{METHODS}

This research is a quantitative research with a cross sectional approach, which is a research conducted by observing or observing data at one time. This means that the research subjects were only observed once and measurements were made on the status of the character or subject variables at the time of examination (Notoatmodjo, 2018). This research was conducted in November 2021at Murni Teguh Memorial Hospital Medan.

The study population was 154 health workers in charge of treating Covid-19 patients at Murni Teguh Memorial Hospital Medan consisting of 5 Internal Medicine Specialists, 5 Pulmonary Disease Specialists, 22 General Practitioners and 122 Nurses. The sample of this study amounted to 61 people consisting of 2 Internal Medicine Specialists, 2 Pulmonary Disease Specialists, 9 General Practitioners and 48 Nurses.Statistical analysis used in finding the effect of the independent and dependent variables in this study is to use quantitative methods.

\section{RESULT AND DISCUSSION}

Based on the results of the study, it can be explained that the independent variables, namely individual factors, psychological factors and organizational factors studied in this study consist of: ability, experience, perception, motivation, availability of human resources and availability of PPE. After statistical tests were carried out, the results showed that the six variables, except for the perception variable, had an effect on performance of health workers in Murni Teguh Memorial Hospital. The results of this study contradict the results of Karyo's research (2016) which found that the experience factor was not related to the performance of emergency nurses. The results of the study are supported by the statement of Wibowo (2017) that one of the three important components that appear in human abilities, namely the skills possessed by employees are based on the experience they do while working. Harefa's research (2021), which found that there is a relationship between ability and performance of health workers at the Kenangan Percut Sei Tuan Health Center, Deli Serdang Regency. The results show that health workers who have good experience also have good performance. This is because experience will add input and increase the skills of health workers because they are used to carrying out their duties in serving patients. Health workers with longer work experience have high performance and are always able to do their jobs well. But there are still 15 respondents or health workers with poor experience. This is because the new officers have finished their education and have just started working.

The results of this study are in line with the results of research by Umar \& Hamdiah (2021) which found there was a significant relationship between public perception and negative public stigma that affected the performance of health workers. Nurses and health workers who struggle to treat patients with wrong perceptions and 
bad stigma will make health workers depressed, stressed and isolated, thereby reducing performance.

The results of this study are also in linewith research results Supriyadi (2017) who discovered motivation, work ethic, work environment, competence and job satisfaction affect the performance of nurses. Harefa's research (2021), which foundthat there is a relationship between work motivation and the performance of health workers at the Kenangan Percut Sei Tuan Health Center, Deli Serdang Regency. Health workers with poor work motivation are more at risk of having poor performance than health workers with good work motivation. Rukhayati's research (2018) shows that motivation partially has a significant influence on the employee performance variable at the Talise Health Center. Research by Marsita (2018) found that there is a relationship between work motivation and the performance of health workers. Zaini's research (2018) shows that there is a moderate relationship between motivation and employee performance.

\section{CONCLUSION}

Based on the results of this study, it was concluded that there werethe influence of individual factors (ability and experience) and organizational factors (availability of human resources and availability of PPE) on the performance of health workers in treating Covid-19 patients at Murni Teguh Memorial Hospital.

There is no influence of psychological factors (perception) and there is the influence of psychological factors (motivation) on the performance of health workers in treating Covid-19 patients at Murni Teguh Memorial Hospital.

\section{ACKNOWLEDGMENTS}

Thank you to the supervisor who has guided to complete this research. And we don't forget to thank the family for the great support to the author.

\section{REFERENCES}

[1] World Health Organization. (2020a). Naming the coronavirus disease (COVID-19) and the virus that causes it. Geneva: World Health Organization. Diakses 29 Januari 2020 dari: https://www.who.int/.

[2] Alhakami, Yahya I \& Baker, Ghazi O. (2018). Nurses' Happiness and Awareness of Their Influence on Work in Governmental and Private Hospitals. Clinical Nursing Studies, 7(1), 21. doi:10.5430/cns.v7n1p21.

[3] Fernandez, P. R., Lord, H., Halcomb, P. E., Moxham, P. L., Middleton, D. R., Alananzeh, D. I., \& Ellwood, L. (2020). Implications for COVID-19: a systematic review of nurses' experiences of working in acute care hospital settings during a respiratory pandemic. International Journal of Nursing Studies, 103637.

[4] Effendi, F \& Makhfudli. (2009). Keperawatan Kesehatan Komunitas : Teori dan Praktek dalam Keperawatan. Jakarta: Salemba Medika. 
[5] Gibson, Ivancevich, \& Donnelly. (2014). Organisasi, Perilaku, Struktur, Proses. Jakarta: Bina Rupa Aksara.

[6] Ilyas, Y. (2016). Kinerja, Teori, Penilaian dan Penelitian. Jakarta: Pusat Kajian.

[7] Karyo dkk, (2016). Analisis Faktor-faktor yang Mempengaruhi Kinerja Perawat Gawat Darurat. Tesis. Universitas Brawijaya.

[8] Wibowo. (2017). Manajemen Kinerja. Edisi kelima, Cetakan ke-12. Jakarta: Rajawali Pers.

[9] Umar, E dan Hamdiah, D. (2021). Dampak Persepsi dan Stigma Masyarakat tentang Covid-19. Faletehan Health Journal, 8 (3) (2021) 203-209 www. journal.lppmstikesfa.ac.id/ojs/index.php/FHJ ISSN 2088-673X| e-ISSN 2597-8667.

[10] Supriyadi, Al Aluf, Wilda, Sudarsih, D.P. Musmedi. (2017). Assessing The Impact Of Motivation, Job Satisfaction, And Work Environment On The employee Performance In Healthcare Services. International Journal Of Scientific \& Technology Research 6 (10): 337-341.

[11] Rukhayati. (2018). Pengaruh Motivasi dan Disiplin Kerja terhadap Kinerja Karyawan di Puskesmas Talise. Jurnal Sinar Manajemen, Vol.5, No2(E-ISSN 2598-398X, P-ISSN 2337-8743), pp. 98-104.

[12] Marsita. S (2018). Faktor-Faktor Yang Berhubungan dengan Kinerja Petugas Kesehatan di Puskesmas Lambunu 2 Kabupaten Parigi Moutong. Skripsi. Fakultas Kesehatan Masyarakat, Universitas Muhammadiyah Palu.

[13] Zani M.R.F (2018). Faktor-faktor yang Berhubungan dengan Kinerja Pegawai Puskesmas Nambo Kota Kendari. Miracle Journal Of Public Health. Vol 1 No 2 (2018). 